\title{
Lung Squamous Cell Carcinoma, Papillary Variant
}

National Cancer Institute

\section{Source}

National Cancer Institute. Lung Squamous Cell Carcinoma, Papillary Variant. NCI

Thesaurus. Code C45502.

A morphologic variant of squamous cell lung carcinoma characterized by the presence of papillary structures. 